\title{
Attributes of the Lower Mississippi River Batture
}

by D. S. Biedenharn, K. J. Killgore, C. D. Little, Jr., C. E. Murphy, and B. A. Kleiss

MRG\&P Technical Note No. 4 • March 2018

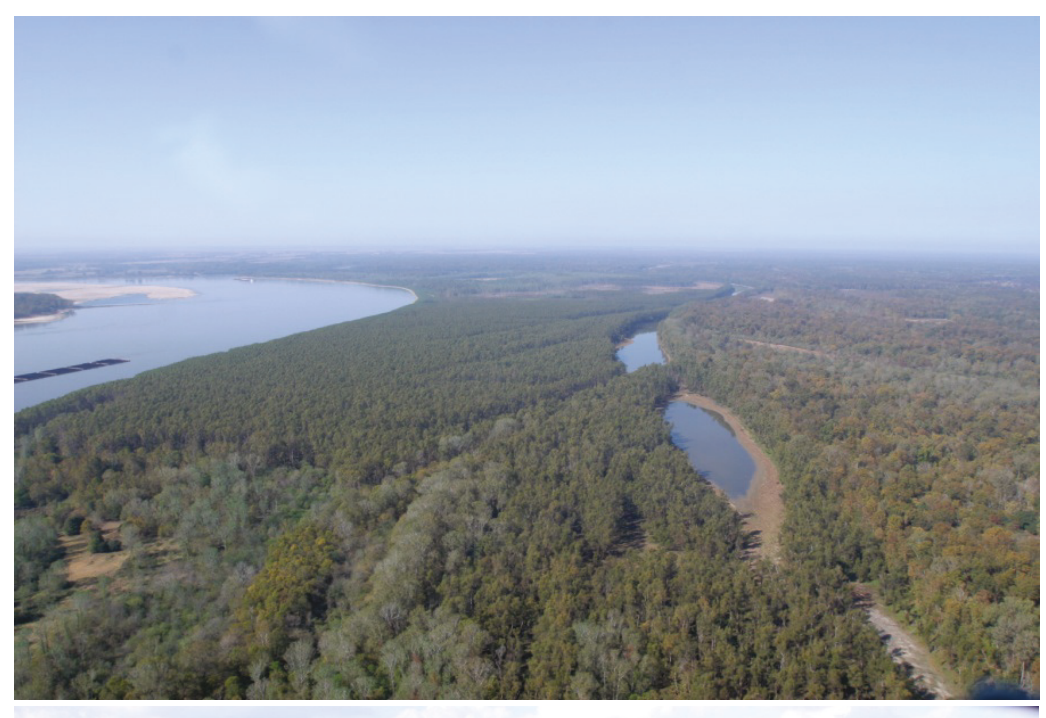

MRG\&P

Mississippi River Geomorphology \& Potamology Program 


\section{MRG\&P \\ Mississippi River Geomorphology \& Potamology Program}

INTRODUCTION: The Lower Mississippi River (LMR) Floodplain is one of the largest in the world. Although the levee system reduced the historic floodplain by $>80 \%$, the remaining land between the levees (batture) is a mosaic of different aquatic and terrestrial habitats. Over 21 million acres are inundated at high water in the LMR including bottomland hardwoods, natural and manmade lakes, floodplain pools, sloughs, and tributary mouths. The ecological value of the batture is reflected by the high biodiversity of aquatic and terrestrial species. The batture sustains the productivity of the main channel, allowing endangered species such as pallid sturgeon to thrive in the LMR. River engineering activities and natural aquatic habitats coexist throughout the LMR, with major contributions from the batture. Together, these attributes make the LMR one of the most important remaining wilderness areas in the United States.

To help characterize the amount of the batture in the LMR, the width of the floodplain between the main stem levees or valley walls was measured on approximate 5-mile intervals. Downstream of Baton Rouge (River Mile [RM] 235), the batture is confined, with an average width of slightly less than 1 mile. However, between Baton Rouge and Cairo, the batture widens significantly, having an average width of almost 6.5 miles. At numerous locations, the batture expands to between 10 to 15 miles in width, with many of these locations being associated with oxbows of old meander cutoffs.

BACKGROUND: Efforts applying river engineering methods to develop navigation and flood control along the Mississippi River and its floodplain have taken place since the eighteenth century, with the most concerted efforts occurring as a result of the Flood Control Act (FCA) of 1928 following the Great Flood of 1927. The Mississippi River \& Tributaries Project that was authorized from the FCA of 1928 has produced a massive, comprehensive system for flood control and channel stabilization that includes levees, channel modifications, and floodways, as well as tributary reservoirs and other basin improvements. Additionally, the development of the river for dependable navigation has generated a substantial engineering effort in terms of river training structures and dredging. The historical, present-day, and future morphology of the Mississippi River reflects an integration of all these features combined with natural factors such as floods and droughts, hurricanes, tectonic activity, geologic outcrops, climatic variability, and sea level rise. Understanding how these various factors affect the short- and long-term morphology of the river is a complex challenge for river engineers and scientists responsible for managing this system for flood control, navigation, and environmental stewardship. The Mississippi River Geomorphology and Potamology (MRG\&P) Program was developed in recognition of this challenge. The MRG\&P Program is a joint effort of the U.S. Army Corps of Engineers (USACE), St. Louis, Memphis, Vicksburg, and New Orleans Districts, conducted with the oversight of the Mississippi Valley Division and benefiting from technical contributions from the U.S. Army Engineer Research and Development Center. The study reported herein is just one of many components of the MRG\&P Program.

The LMR Floodplain is one of the largest in the world. Although the levee system reduced the historic floodplain by $>80 \%$, the remaining land between the levees (batture) is a mosaic of different aquatic and terrestrial habitats. Over 2.2 million acres are inundated at high water in the LMR including bottomland hardwoods, natural and manmade lakes, floodplain pools, sloughs, and 


\section{MRG\&P \\ Mississippi River Geomorphology \& Potamology Program}

tributary mouths. The ecological value of the batture is reflected by the high biodiversity of aquatic and terrestrial species. The batture sustains the productivity of the main channel, allowing endangered species such as pallid sturgeon to thrive in the LMR.

OBJECTIVES OF STUDY: The objectives of this study were to document the physical characteristics and ecological importance of the LMR batture areas. The study area is shown in Figure 1. For this study, all river miles are measured Above Head of Passes (AHP).

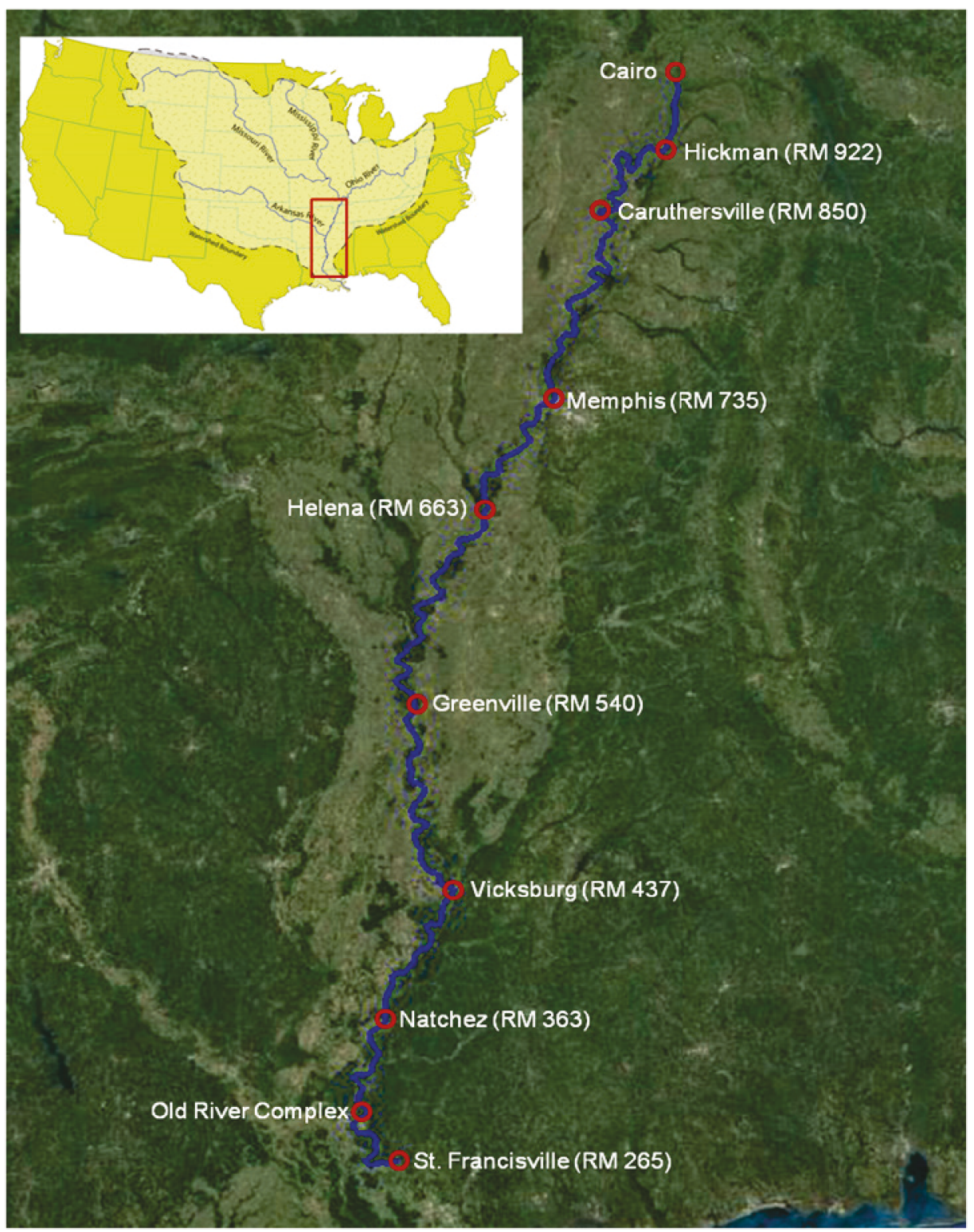

Figure 1. LMR study reach. 


\section{MRG\&P \\ Mississippi River Geomorphology \& Potamology Program}

\section{MORPHOLOGIC ATTRIBUTES OF THE LOWER MISSISSIPPI RIVER}

Meander Cutoff Program on the Lower Mississippi River. As discussed in the Background section, the morphology of the LMR reflects an integration of many natural and anthropogenic factors such as dikes, revetments, levees, meander cutoffs, maintenance dredging, upstream dams, land use and soil conservation efforts (e.g., sediment retention, erosion control, and water management structures, vegetative filter strips, cover crops, conservation tillage, and reforestation), floods and droughts, and climate change. However, the single event that resulted in stage reductions and morphologic adjustments that were larger and more abrupt than those associated with any other event over the last 100 years was construction of the meander cutoffs between 1929 and 1942. To better understand these events, some background about the development of the meander cutoffs is necessary.

There are two types of cutoffs on the LMR: neck cutoffs and chute cutoffs (Winkley 1977; Walters 1975). As shown in Figure 2, a neck cutoff occurs due to the progressive erosion of two bends of a meander loop until the narrow strip of land between the loops is completely breached, resulting in the abandonment of the old meander. This typically results in a dramatic shortening of the river. In contrast, a chute cutoff (Figure 3 ) occurs as successive high water flows develop a secondary channel (chute) across the inside of the point bar. This often results in a divided flow condition between the two channels until such time that the older channel deteriorates in favor of the new main channel. While there is some river shortening associated with the chute cutoffs, the relative magnitude of the reduction is small compared to the neck cutoffs.

Meander cutoffs are part of the natural process whereby alluvial rivers maintain the ability to transport water and sediment within a stable regime. A river in dynamic equilibrium may be increasing in length in some locations through meander migration while meander cutoffs may shorten the length in others: the net result is that the river maintains a certain length, which translates into a consistent slope and sediment transport capacity over time. This meandering process can be illustrated by considering the LMR between the years 1776 and 1884. During this period, 18 cutoffs occurred (16 natural and 2 man-made) between just south of Caruthersville, MO, and Red River Landing, LA, which shortened this 640 mile reach by approximately 218 miles (Table 1). However, due to meander migration during this period, the difference in total length between 1776 and 1884 in this reach was only approximately 8 miles (Winkley 1977). 


\section{MRG\&P}

Mississippi River Geomorphology \& Potamology Program

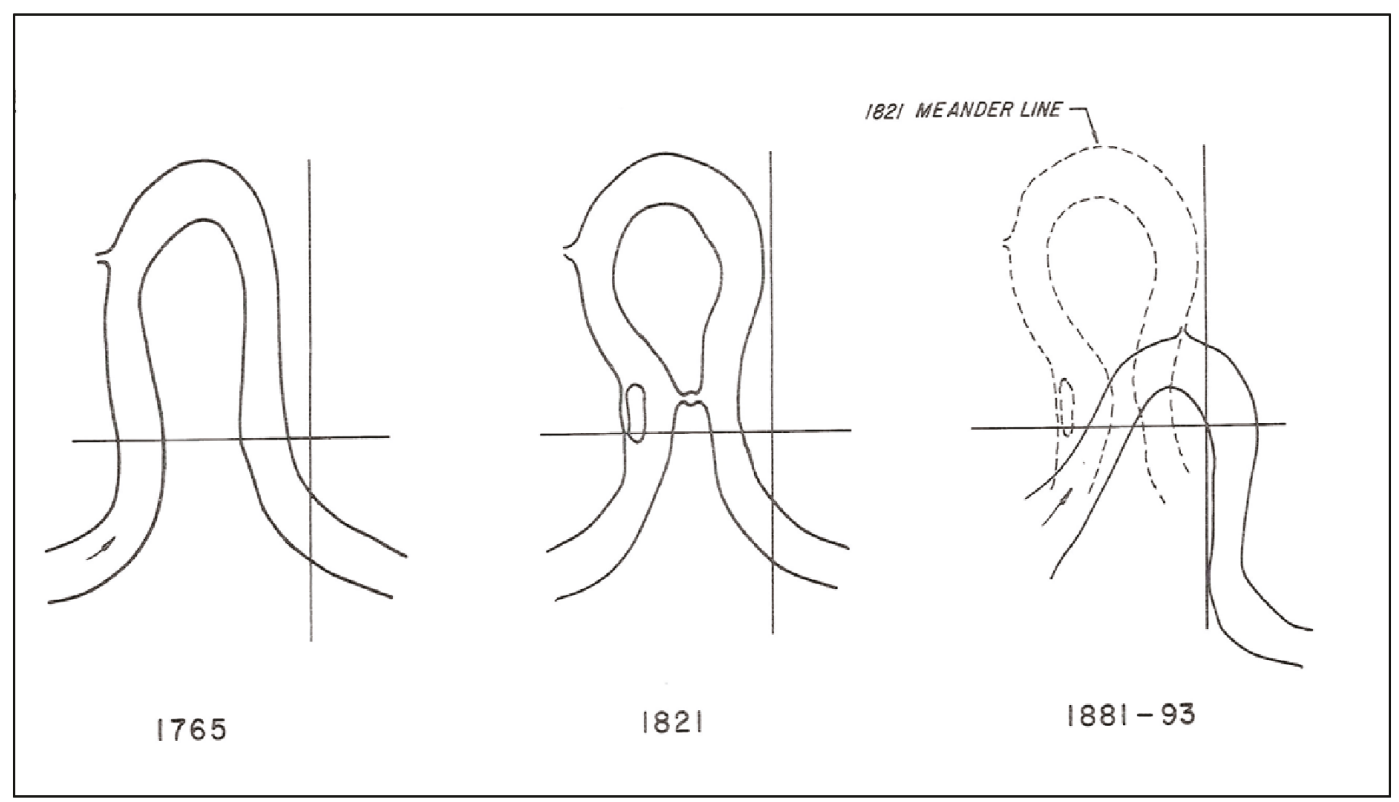

Figure 2. Typical neck cutoff on the LMR (after Walters 1975).

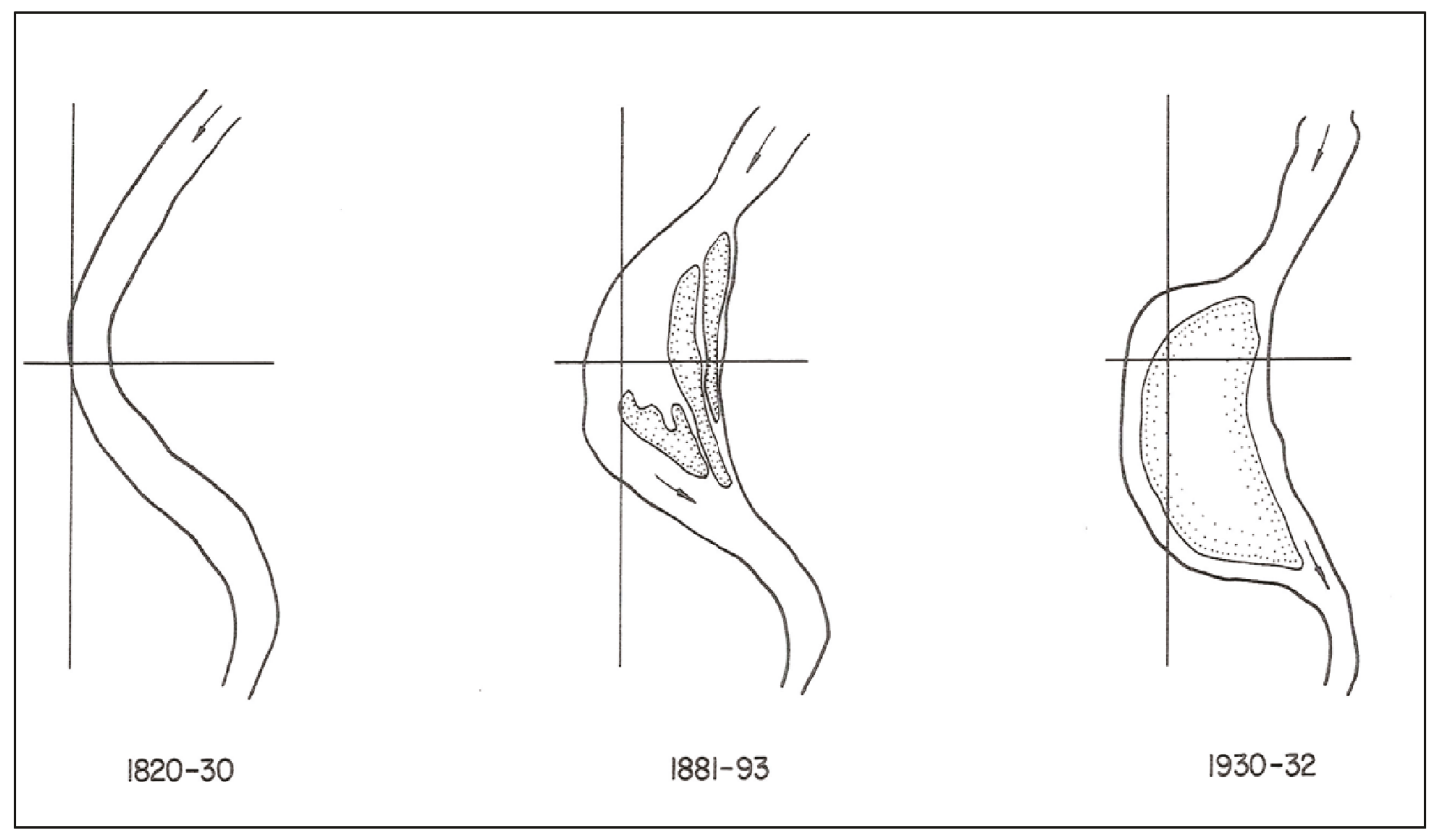

Figure 3. Typical chute cutoff on the LMR (after Walters 1975). 
Mississippi River Geomorphology \& Potamology Program

\begin{tabular}{|c|c|c|c|}
\hline Cutoff Name & River Mile* & $\begin{array}{l}\text { Year Cutoff } \\
\text { Occurred }\end{array}$ & $\begin{array}{l}\text { River Length } \\
\text { Reduced by } \\
\text { Cutoff (miles) }\end{array}$ \\
\hline Needhams & 820 & 1821 & 11 \\
\hline Centennial (Devil's Elbow) & 754 & 1876 & 15 \\
\hline Commerce & 690 & 1874 & 10 \\
\hline Bordeaux Chute & 680 & 1874 & 7 \\
\hline Montezuma & 656 & 1817 & 11 \\
\hline Horseshoe & 650 & 1848 & 8 \\
\hline Napoleon (Beulah Lake) & 584 & 1863 & 10 \\
\hline American & 525 & 1858 & 11 \\
\hline Grand Lake & 508 & 1817 & 10 \\
\hline Bunches Bend & 505 & 1830 & 12 \\
\hline Terrapin Bend & 462 & 1866 & 16 \\
\hline Yazoo & 442 & 1799 & 12 \\
\hline Centennial Lake & 438 & 1876 & 6 \\
\hline Davis (Palmyra) & 422 & 1867 & 19 \\
\hline Waterproof & 377 & 1884 & 12 \\
\hline Homochitto & 322 & 1776 & 13 \\
\hline Shreves ${ }^{* *}$ & 303 & 1831 & 15 \\
\hline Raccourci** $^{* *}$ & 299 & 1848 & 19 \\
\hline
\end{tabular}

Man-made cutoffs. Beginning in 1884, the USACE Mississippi River Commission adopted a no-cutoff policy. This policy initiated a large-scale bank protection program aimed at preventing meander migration and the development of meander cutoffs. The no-cutoff policy continued until 1929 when a natural cutoff was allowed to develop at Yucatan, approximately 30 miles south of Vicksburg. After a few years of monitoring of the river's response to the Yucatan cutoff, a program of channel realignment was incorporated into the Mississippi River \& Tributaries (MR\&T) plan for the basin. In total, the USACE constructed 14 artificial cutoffs and allowed 2 natural cutoffs (Yucatan and Leland) to develop between 1929 and 1942 on the LMR. The location and description of the cutoffs are shown in Table 2 and Figure 4. These cutoffs shortened the river between Memphis, TN, and Old River, LA, by approximately 152 miles. Since 1942, no neck cutoffs have been constructed or allowed to develop. However, between 1932 and 1955, chute cutoffs constructed at 40 locations between Cairo, IL, and Natchez, MS, further shortened the river by another 55 miles. Following the cutoffs, the river attempted to regain some of its length through increased meandering until the 1960s when revetments essentially stopped future migration. However, according to Winkley (1977), the length increases were offset by the chute cutoffs so that the river is still approximately 150 miles shorter than prior to the cutoffs. 
Mississippi River Geomorphology \& Potamology Program

\begin{tabular}{|c|c|c|c|}
\hline Cutoff Name & River Mile* & Year Opened & $\begin{array}{c}\text { Distance River } \\
\text { Shortened (miles) }\end{array}$ \\
\hline Hardin & 678 & 1942 & 16.9 \\
\hline Jackson & 628 & 1941 & 8.7 \\
\hline Sunflower & 625 & 1942 & 10.4 \\
\hline Caulk & 575 & 1937 & 15.2 \\
\hline Ashbrook & 549 & 1935 & 11.4 \\
\hline Tarpley & 541 & 1935 & 8.6 \\
\hline Leland ${ }^{*}$ & 539 & 1933 & 9.8 \\
\hline Worthington & 514 & 1933 & 4.3 \\
\hline Sarah & 504 & 1936 & 5.3 \\
\hline Willow & 463 & 1934 & 7.7 \\
\hline Marshall & 448 & 1934 & 4.2 \\
\hline Diamond & 424 & 1933 & 12 \\
\hline Yucatan* & 408 & 1929 & 9.6 \\
\hline Rodney & 388 & 1936 & 5.9 \\
\hline Giles & 366 & 1933 & 11.1 \\
\hline Glasscock & 343 & 1933 & 10.8 \\
\hline \multicolumn{3}{|c|}{ Total } & 151.9 \\
\hline *Natural cutoff & & & \\
\hline
\end{tabular}

The shortening and steepening of the river caused by the cutoffs triggered complex morphologic adjustments that continue to the present day. A recent MRG\&P study (Biedenharn et al. 2017) concluded that the river is responding in a fashion typical of the adjustments expected in an alluvial stream subjected to a program of meander cutoffs: decreasing stage trends (degradation) that migrate upstream and increasing stage trends (aggradation) that progress downstream. More detailed studies are planned as part of the MRG\&P Program to develop a better understanding of the long-term morphologic response of the river to the cutoffs and other natural and anthropogenic factors. 


\section{MRG\&P}

Mississippi River Geomorphology \& Potamology Program

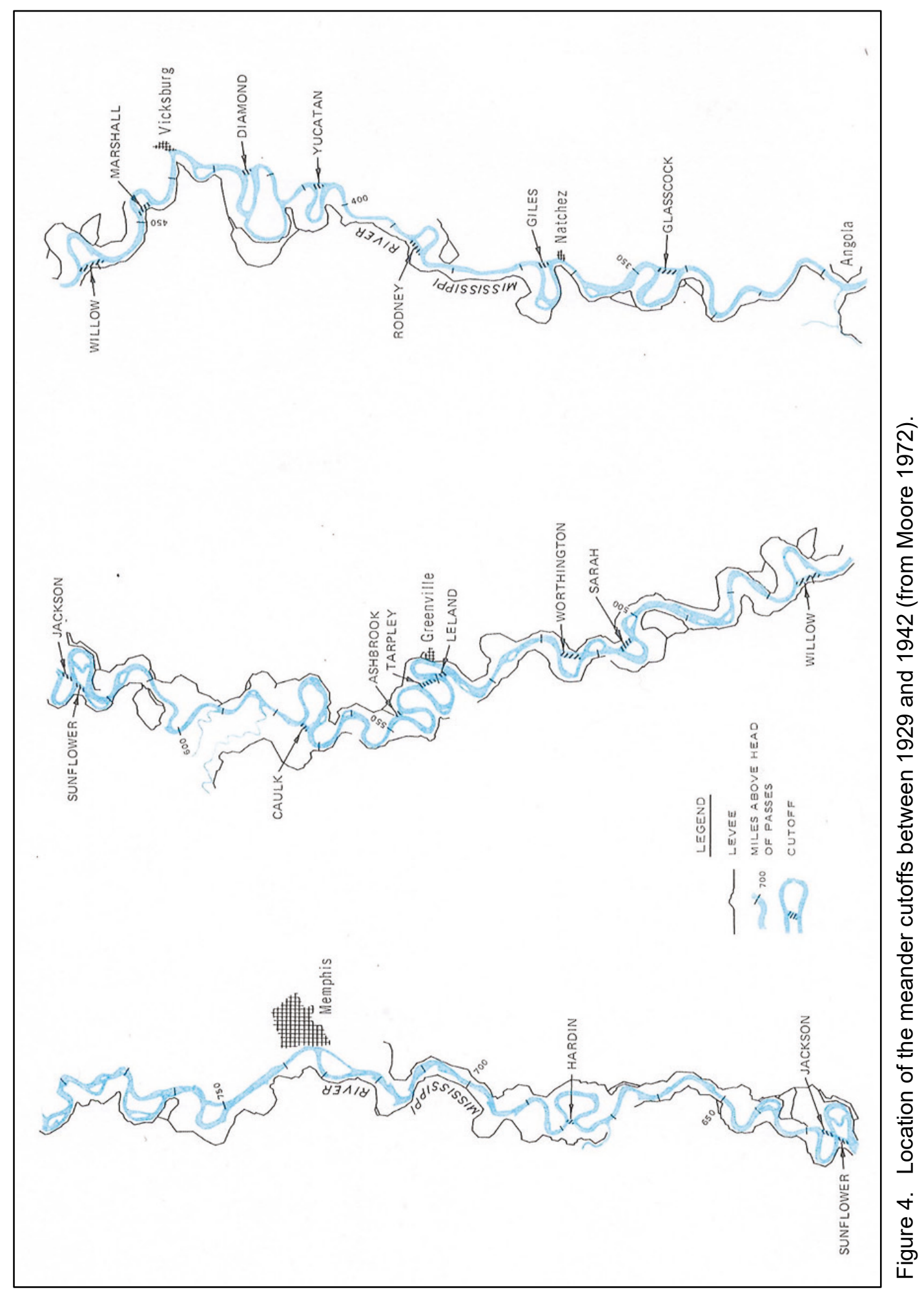




\section{MRG\&P \\ Mississippi River Geomorphology \& Potamology Program}

BATTURE WIDTH ALONG THE LOWER MISSISSIPPI RIVER: The cutoffs have been hailed by many as a great success with respect to flood control and navigation, but others have highlighted the severe morphological adjustments and environmental degradation associated with the cutoffs (Winkley 1977; U.S. Army Corps of Engineers 1982; Elliott et al. 1991; Biedenharn et al. 2000). While the negative impacts of the cutoffs are often debated, one positive aspect that has not been widely recognized is the environmental importance of the oxbow lakes and their associated floodplain created by cutoffs.

A major component of the MR\&T Project is the main stem levees along the river. On the west bank, the main stem levees begin just south of Cape Girardeau, MO, and extend nearly continuously to Venice LA. The only gaps occur where tributaries enter the river. High bluffs along the east bank of the river eliminate the need for levees in many areas. Therefore, the main stem levees along the east bank begin near Hickman, KY, and extend intermittently to just above Vicksburg, MS. The levees start again at Baton Rouge and proceed continuously to Pointe a la Hache relief outlet near Bohemia, LA. This levee system is a critical component of the MR\&T flood control plan. However, it has also resulted in the removal of approximately $80 \%$ of the historic floodplain of the LMR. While this is a considerable loss of a valuable resource, it should also be recognized that there are still vast amounts of batture areas (land between the levees) within the levee system.

To help characterize the amount of the batture in the LMR, the width of the floodplain between the main stem levees or valley walls was measured on approximate 5-mile intervals between RM 45 near Bohemia, LA, and RM 954 just south of Cairo, IL (Figure 5). As shown in Figure 5, the batture is confined downstream of Baton Rouge (RM 235) with an average width of slightly less than 1 mile. However, between Baton Rouge and Cairo, the batture widens significantly, having an average width of almost 6.5 miles. At numerous locations, the batture expands to between 10 to 15 miles in width.

Many of the wider batture locations described above coincide with old meanders created by the natural and man-made cutoffs which were constructed between 1776 and 1942. An important design component of the main stem levee plan was that most of the old bendway channels were not closed off, which provided connectivity of floodwaters back to the levees or valley walls. Table 3 shows a list of all cutoffs (natural and man-made) between 1776 and 1942 along with the batture width associated with each. As shown in Table 3, all but three of the old meanders of the cutoffs between 1776 and 1884 are contained within the main stem levees, with the average width of the batture being approximately 7.5 miles. All 16 of the man-made cutoffs (1929-1942) are within the main stem levees (Table 3 ). The average batture width at these man-made cutoffs is approximately 9.1 miles. 


\section{MRG\&P}

Mississippi River Geomorphology \& Potamology Program

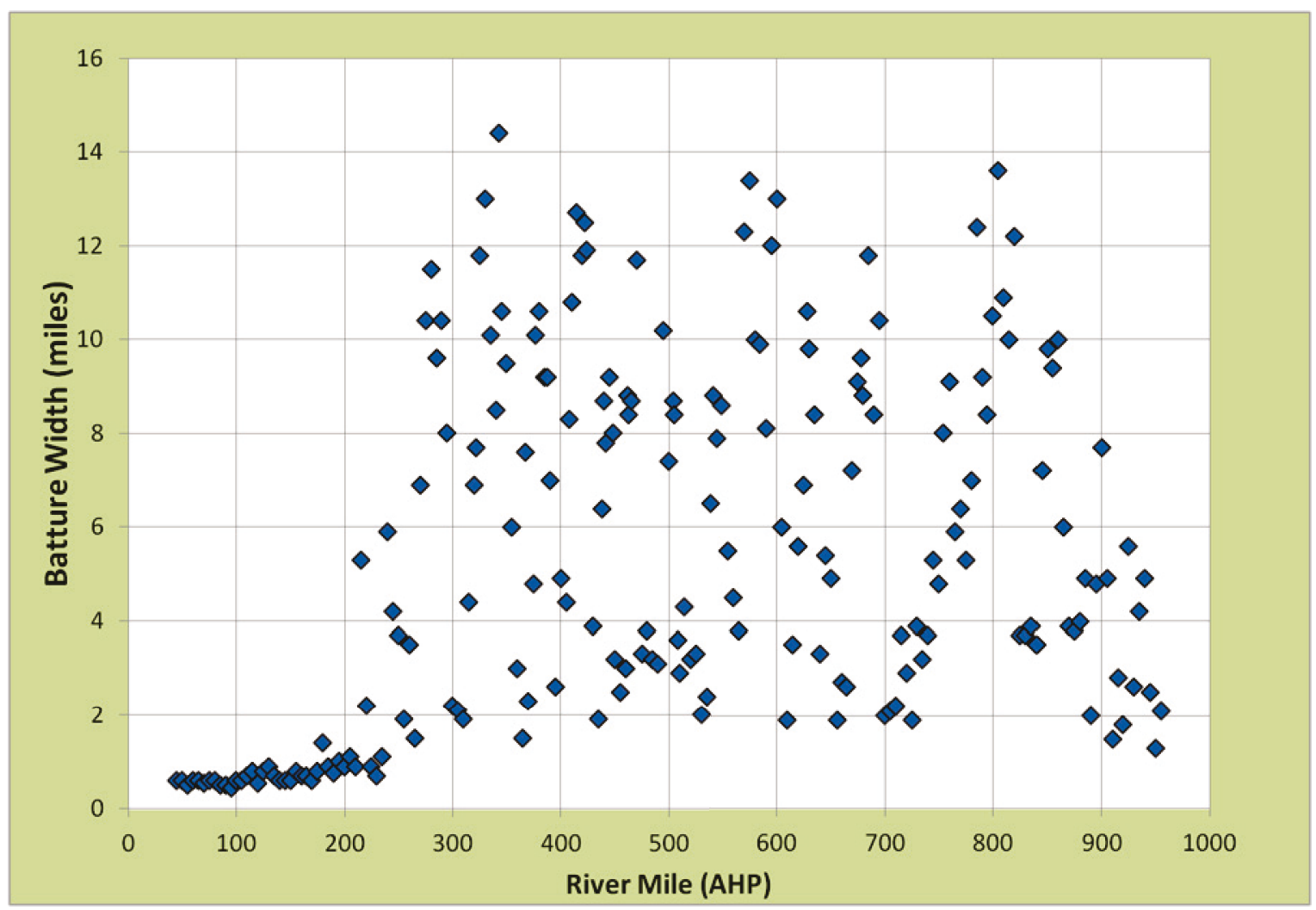

Figure 5. Batture width along the LMR.

\begin{tabular}{|l||c||c|c||}
\hline \hline \multicolumn{3}{|l|}{ Table 3. Batture widths at meander cutoffs between 1776 and 1942.} \\
\hline \hline Cutoff Name & $\begin{array}{c}\text { Old Meander } \\
\text { Contained within } \\
\text { Main-Stem } \\
\text { Levee? }\end{array}$ & $\begin{array}{c}\text { Batture Width } \\
\text { (miles) }\end{array}$ \\
\hline \hline \multicolumn{2}{|c|}{ Cutoffs between 1776 and 1884 } \\
\hline Needhams & 820 & Yes & 12.2 \\
\hline Centennial (Devil's Elbow) & 754 & Yes & 8 \\
\hline Commerce & 690 & Yes & 10.4 \\
\hline Bordeaux Chute & 680 & Yes & 8.8 \\
\hline Montezuma & 656 & No & 1.9 \\
\hline Horseshoe & 650 & Yes & 4.9 \\
\hline Napoleon (Beulah Lake) & 584 & Yes & 9.9 \\
\hline American & 525 & Yes & 3.3 \\
\hline Grand Lake & 508 & No & 3.6 \\
\hline Bunches Bend & 505 & Yes & 8.4 \\
\hline Terrapin Bend & 462 & No & 8.8 \\
\hline Yazoo & 442 & Yes & 7.8 \\
\hline
\end{tabular}


Mississippi River Geomorphology \& Potamology Program

\begin{tabular}{|c|c|c|c|}
\hline Cutoff Name & River Mile* & $\begin{array}{c}\text { Old meander } \\
\text { contained within } \\
\text { main-stem levee? }\end{array}$ & $\begin{array}{c}\text { Batture Width } \\
\text { (miles) }\end{array}$ \\
\hline Centennial Lake & 438 & Yes & 6.4 \\
\hline Davis (Palmyra) & 422 & Yes & 12.5 \\
\hline Waterproof & 377 & Yes & 10.1 \\
\hline Homochitto & 322 & Yes & 7.7 \\
\hline Shreves ${ }^{* *}$ & 303 & No & 2.1 \\
\hline Raccourci** $^{* *}$ & 299 & Yes & 8 \\
\hline \multicolumn{3}{|c|}{ Average Batture Width } & 7.5 \\
\hline \multicolumn{4}{|c|}{ Man-Made Cutoffs between 1929 and 1942} \\
\hline Hardin & 678 & Yes & 9.6 \\
\hline Jackson & 628 & Yes & 10.6 \\
\hline Sunflower & 625 & Yes & 6.9 \\
\hline Caulk & 575 & Yes & 13.4 \\
\hline Ashbrook & 549 & Yes & 8.6 \\
\hline Tarpley & 541 & Yes & 8.8 \\
\hline Leland* & 539 & Yes & 6.5 \\
\hline Worthington & 514 & Yes & 4.3 \\
\hline Sarah & 504 & Yes & 8.7 \\
\hline Willow & 463 & Yes & 8.4 \\
\hline Marshall & 448 & Yes & 8 \\
\hline Diamond & 424 & Yes & 11.9 \\
\hline Yucatan* & 408 & Yes & 8.3 \\
\hline Rodney & 388 & Yes & 9.2 \\
\hline Giles & 366 & Yes & 7.6 \\
\hline Glasscock & 343 & Yes & 14.4 \\
\hline \multicolumn{3}{|c|}{ Average Batture Width } & 9.1 \\
\hline $\begin{array}{l}{ }^{*} 1962 \text { river miles } \\
\text { **Man-made cuto }\end{array}$ & & & \\
\hline
\end{tabular}

ECOLOGICAL ATTRIBUTES OF THE LOWER MISSISSIPPI RIVER: The LMR is part of a 1,959-mile corridor of the free-flowing Missouri-Mississippi River, which is the largest of its kind in the United States. Unobstructed from Gavin's Point Dam on the Missouri River down to the Gulf of Mexico, the LMR and its floodplain drain almost $41 \%$ of the continental United States and a portion of Canada. Shovelnose sturgeon externally tagged in the LMR have been captured in the Missouri River, some traveling over 1,000 miles. Similar movements have been documented from the Missouri River down into the LMR. Not only is the LMR the lowermost reach of this river system, it has the largest, most intact floodplain of any river system in the United States.

Batture width in the LMR, traversing up to almost 15 miles at some locations, creates a heterogeneous floodplain supporting almost 100 species of fish (Baker et al. 1991). The unregulated flow of the LMR maintains a natural hydrograph periodically connecting oxbow lakes, sloughs, forested lands, and other aquatic habitats in the batture. Fish move from the channel into 


\section{MRG\&P \\ Mississippi River Geomorphology \& Potamology Program}

the batture for spawning, rearing, and feeding following the flow paths that form as the river rises (Junk et al. 1989). Resident fish living in batture waterbodies receive food and nutrients from the river water contributing to increased somatic growth and survival. The ebb and flow of floodwater in the batture benefits many other groups of animals contributing to its high biodiversity.

The swales and sloughs in the batture, along with secondary channels and oxbow lakes, can be described based on the type of hydrologic connectivity with the river. Ward and Stanford (1995) adopted terminology arrayed along a gradient of connectivity used for the French Rhône based on attributes of connectivity, successional trajectory, and community structure (Figure 6). In the LMR, a gradient of decreasing connectivity occurs from secondary channels with consistent connection (eupotamal) to isolated pools that connect only during extreme high-water events (paleopotamal). Most oxbows lakes in the LMR are connected to the river only at one end (parapotomal). Many secondary channels shift from eupotamal to parapotamal as river elevation declines during the year. Remnants of lakes or sloughs may not directly connect to the river on either end (pleisopotamal) but through smaller connecting channels, ditches, or overland. As part of the MRG\&P Program, studies are being conducted in the LMR to evaluate biotic communities across the gradient of connectivity to better understand the ecological value of the free-flowing LMR as a reference condition for other great rivers.

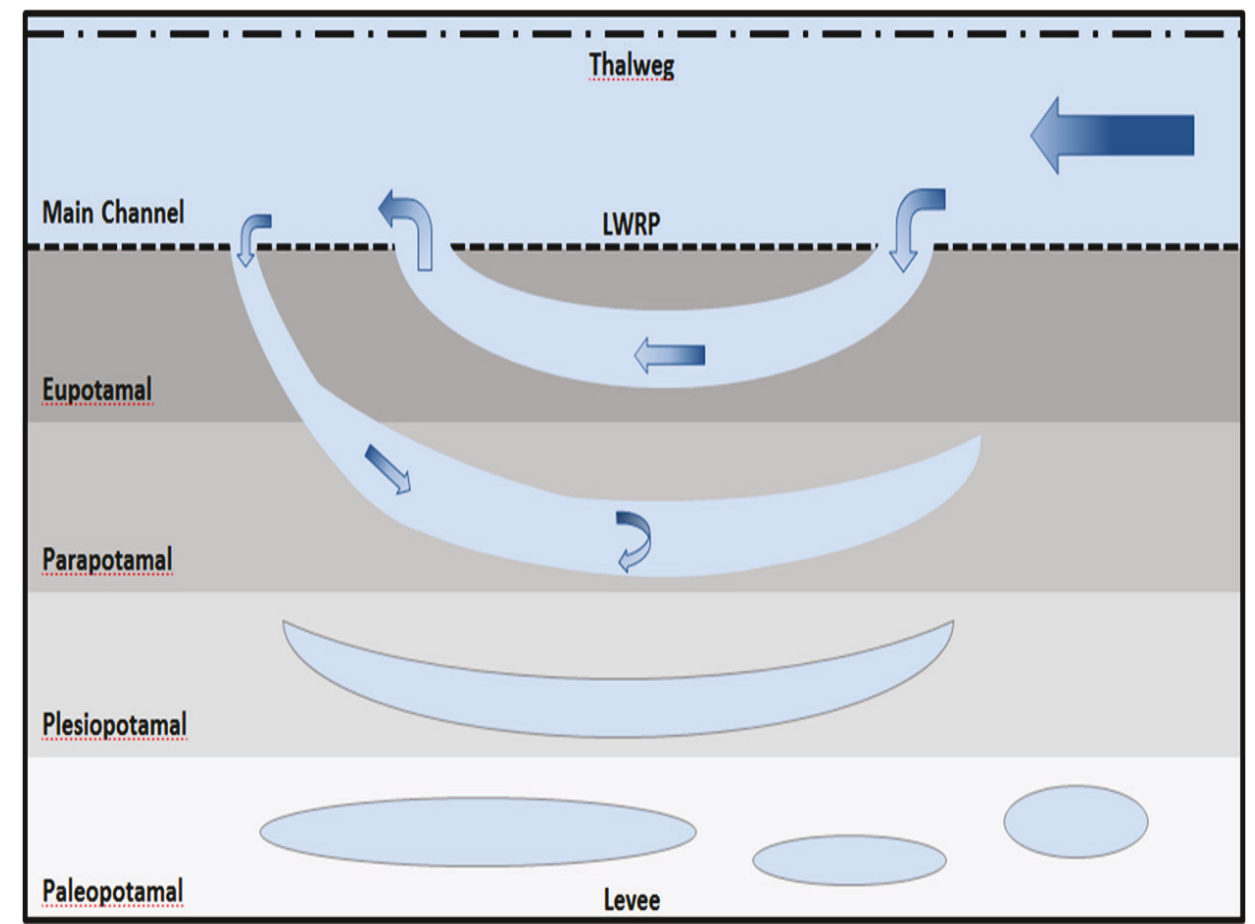

Figure 6. Typology of connectivity between river and batture. 


\section{MRG\&P \\ Mississippi River Geomorphology \& Potamology Program}

SUMMARY: This study documented the morphological and ecological attributes of the batture areas along the LMR. A summary of significant findings follows.

- The LMR floodplain, or batture, is one of the most important remaining wilderness areas in the U.S., encompassing over 2.2 million acres.

- The LMR has the largest, most intact floodplain of any river system in the United States.

- High biological productivity in the main channel is sustained by the seasonal inundation of the batture and the diversity of floodplain waterbodies that occur throughout the LMR.

- The average width of the batture between Baton Rouge, LA and Cairo, IL, is approximately 6.5 miles.

- At many locations, the width of the batture expands from 10 to almost 15 miles.

- Many of the wider batture locations coincide with old meanders created by the natural and man-made cutoffs that were constructed between 1776 and 1942.

- Conservation and restoration of the batture will ensure its ecological contribution to the LMR.

- As part of the MRG\&P Program, studies are being conducted in the LMR to evaluate biotic communities across the gradient of connectivity to better understand the ecological value of the free-flowing LMR as a reference condition for other great rivers.

\section{REFERENCES}

Baker, J. A., K. J. Killgore, and R. L. Kasul. 1991. "Aquatic Habitats and Fish Communities in the Lower Mississippi River." Reviews in Aquatic Sciences 3(4): 313-356.

Biedenharn, D. S., C. R. Thorne, and C. C. Watson. 2000. "Recent Morphological Evolution of the Lower Mississippi River." Geomorphology 34(3-4). https://doi-org/10.1016/S0169-555X(00)00011-8.

Biedenharn, D. S., M. A. Allison, C. D. Little, C. R. Thorne, and C. C. Watson. 2017. Large-Scale Geomorphic Change in the Mississippi River from St. Louis, MO, to Donaldsonville, LA, as Revealed by Specific Gage Records. MRG\&P Report No. 10. Vicksburg, MS: U.S. Army Engineer Research and Development Center. http://dx.doi.org/10.21079/11681/22744.

Elliot, C. M, R. R. Rentschler, and J. H. Brooks. 1991. "Response of the Lower Mississippi River Low-Flow Stages." In Proceedings of the Fifth Federal Interagency Sedimentation Conference, March 18-21, Las Vegas, NV. Edited by S.-S. Fan and Y.-H. Kuo, 4-16 - 4-23, Volume 1 (Section 4). https://pubs.usgs.gov/misc/FISC 1947-2006/pdf/1st-7thFISCs-CD/5thFISC/5Fisc-V1/5Fisc14.PDF\#page $=18$.

Junk, W., P. B. Bayley, and R. E. Sparks. 1989. "The Flood Pulse Concept in River-Floodplain Systems.” Canadian Special Publication of Fisheries and Aquatic Science 106: 110-127. 


\section{MRG\&P \\ Mississippi River Geomorphology \& Potamology Program}

U.S. Army Corps of Engineers (USACE). 1982. Analysis of Major Parameters Affecting the Behavior of the Mississippi River. Potamology Program (P-1), Report 4. Edited by J. R. Tuttle and W. Pinner. December, 67. Vicksburg, MS: U. S. Army C or p of Engineers, Lower Mississippi Valley Division, Potamology Branch. http://hdl.handle.net/11681/3099.

Walters, W. H. 1975. Regime Changes of the Lower Mississippi River. M.S. Dissertation, Colorado State University, Fort Collins, CO.

Ward, J. V., and J. A. Stanford. 1995. "Ecological Connectivity in Alluvial River Ecosystems and its Disruption by Flow Regulation." Regulated Rivers: Research and Management 11: 105-119. https://doiorg/10.1002/rrr.3450110109.

Winkley, B. R. 1977. Man-Made Cutoffs on the Lower Mississippi River, Conception, Construction, and River Response. Potamology Investigations Report No. 300-2. Vicksburg, MS: U.S. Army Corps of Engineers, Vicksburg District. http://hdl.handle.net/11681/3153. 